\title{
DEVELOPING A DOMINANTLY MISSIONARY CHURCH
}

\author{
By RALPH E. DIFFENDORFER
}

ONE year after the United States entered the great war there was willingness to pursue it to a victorious end at whatever cost, a far more unanimous determination than even the most hopeful dared to expect. More than a hundred million people, made up of great blocks of foreign born and the children of foreign born, have passed from a provincial disinterestedness through the stages of passivist opposition to a more or less intelligent and certainly to a whole-hearted acceptance of a mighty task. The nation became absolutely united on the subject of the war.

The processes by which the American people have been brought to this state of mind and action have caused me a good deal of reflection on the gigantic task of the Christian Church in the world and on its constructive program of establishing the kingdom of God-of peace, righteousness and joy on the earth. Without attempting an analogy, I desire to offer some suggestions, more especially on the educational processes which apparently must be undertaken to make world conquest on the part of the Church at all feasible.

1. There must be presented to the Church definitely and concretely an adequate world program. The determination of such a program is, of course, not a problem for the great mass of church people. The leaders of missionary movements must, of necessity, formulate the program. They will first of all make a survey in detail of the world's moral and spiritual needs as they are related to the social and physical life of the peoples of the earth. 
The Centenary Movement of the Methodist Episcopal Church, which is a church-wide effort to celebrate the one hundredth anniversary of the organization of the Methodist Missionary Society in America by raising $\$ 80,000,000$ to cover the needs of the Church for a fiveyear program of advance at home and abroad, began in just this way. Such a survey to be of any value must be specific and concrete. As determining a program, the survey should be accompanied by definite and concrete statements of the methods by which these needs are to be met. These proposed methods must be sufficiently clear in order that they may become actually operative, subject, of course, to possible revision in the light of further progress. The making of such a survey will in itself be a tremendous educational factor for a large part of the Church. In order that such a program may not appear to be handed down for acceptance to an unwilling Church, strong leaders and members in each locality should be assembled to make the investigations, a plan easily applicable to the needs of both the home Church and the mission field. The socalled 'native Christians' are now passing into membership in a world Church and should always be included by the Church as an increasing factor in its program for world redemption. The educational value of these studies of local people in the territory around well-established churches, as well as in purely missionary fields, will be increasingly apparent, especially when it is understood that they are to be made the basis of a program the realization of which it is expected confidently to attempt.

The point which I wish to make here is that no educational process is very effective, in these days of great undertakings, unless it is closely related to some definitely proposed act. This is clearly the implication of modern functional psychology. Heretofore, in our study of missions both in the class and in the general education of the Church the procedure has been too academic, too largely based on the supposition that action will follow study. 


\section{A Dominantly Missionary Church}

As a matter of fact, action is more immediately dependent on the stirring of the emotions. This has been illustrated time and again in the education of America to its war activity. Knowledge guides rather than incites activity. This does not mean that action arises without interest and information. It only suggests that facts should be linked to proposed action. Missions are the action part of the Church. If public worship, though it has also a strong social value, is the out-reach of the Church toward God, the missionary program is the functioning of the Church among men.

The first step, therefore, in making the Christian Church dominantly missionary is to present to it a thoroughly practicable and realizable objective in the terms of a definite world program. The statements 'to carry the Gospel to the ends of the earth' and 'to establish the Church in the world' are not what is meant by a program of work or action by the Church. These are the popular phrases by which the Church's program has been promulgated in the past, but they are ineffective in a day when men demand concreteness in both method and message.

2. A dominantly missionary Church must have an intelligent interest in its program. More books are now being read and studied in America on the life of the peoples of the belligerent nations than could ever have been hoped for or realized on a purely cultural basis. Immediately upon the declaration of war by the United States, a Bureau of Public Information was organized in Washington. To refer again to our experience in the Methodist Centenary, as soon as the world program was announced, the demand for information became so great that a large special Bureau of Publicity and Education had to be formed, and popular text-books were prepared which described and illustrated the program at home and abroad. Deputations were organized and groups of men and women, even in war times, have gone abroad and others have visited our con- 
gested city centres, our foreign-speaking and industrial colonies, our decadent rural sections and our negro and Mexican racial storm centres. There is no educational process equal to actual observation under trained leaders.

The needs discovered in the survey form the large part of the educational material. The purely cultural material has little or no value. The people want to know the why of the big program. The uninterested become eager when they see that something big is proposed. Next to visitation, pictures are the most compelling. Maps, drawn specially to illustrate and locate needs and projects; charts, showing in striking form the statistics and facts discovered in the survey; floor plans and architects' elevations of proposed new buildings; popular publicity articles describing what is involved in the program-all these are factors in securing the intelligent interest of the people in the undertaking. Pictures, maps, charts and striking sentences are all made into lantern slides, of a quality comparable with the magnitude and dignity of a worthy cause. The educational value of showing people why a big program should be undertaken is enormous and permanent. Provincialism, apathy and active opposition break down and are removed in such a campaign of education. It will be noted that all this interest is aroused because something to be done has been proposed.

For many years in our missionary education we have been trying to educate leaders. We may well ask, leaders for what? Having put on a campaign of education, or organized and held a conference, then a 'continuation committee' was formed to discover ways and means of following up the campaign in order to conserve the interest. We have all felt that much of our effort has come to naught, for the simple reason that there was no program for which leaders were to be trained. The Methodists are training 100,000 ministers and laymen to carry out their campaign of raising $\$ 80,000,000$. Men and women now want to be trained. They are asking to be enrolled. They 
are buying the books. They seek personal interviews. They ask, 'How may I become efficient ?' The difference is that a big job is to be done. They know before they start their training that they are to prepare for some definite task, a part of the great program.

3. A dominantly missionary Church will accept its program willingly. The voluntary acceptance of the burdens and sacrifices of the war has been America's most precious experience thus far. It is the glorious right of a free people. The plan of public education sought this acceptance as a definite end. So may it be with the Christian Church in its program of world conquest. The material of missionary education must uncover the world's great needs, not in terms of theology or in the cant phrases of the classroom, but in the concrete language of everyday life that all people understand.

The program, of course, must be reasonable. A willing acceptance is based upon an appeal to reason. The facts must be forthcoming. Mistakes must be acknowledged. Debatable issues must be discussed. Questions will be asked and must be answered open-mindedly. A democratic people will not stand for 'putting something across' on them, especially during a war for democracy. Education will make this unnecessary. Discussion will do more to clear men's thinking and at the same time lift the vision than almost any other method. Thus far in our missionary education we have tried to get up discussions or debates on suppositional questions. 'If you had a $\$ 1000$ to give to missions would it be more effective to put it in a hospital than in a school ?' and so on. Such discussions may be academically interesting. They seldom achieve actual results. Discussion of a real program, however, if it brings about a willing acceptance, is an educational victory.

Willing acceptance of a program depends upon the ' worth-while-ness' of the objectives. It was so with the aims of the great war. In America, it was not until President Wilson uttered his now world-known phrase, "To make the 
world safe for democracy,' that our people really grasped the significance of the war and accepted its moral aims. It is my clear conviction that before any great program of Christian advance can be achieved in the world there must be a thorough discussion of the aims of such a program. Something more than our individualistic aims of the past will be required by a people who in this great day have seen the utter breakdown of individualism as a philosophy of life. The sectarian propaganda both at home and abroad has almost thwarted our efforts to establish the kingdom of God on earth. It is not my purpose here to discuss what these aims ought to be, but to point out that for the purposes of developing a dominantly missionary Church the great aims of the missionary enterprise must be restated in terms of present-day thinking, and even more, in terms of to-morrow's world life.

Again, if I may refer to the Methodist Centenary program, the phrase which has apparently caught the imagination of people and paved the way for willing acceptance of their tremendous task is the pregnant and vitally significant watchword, "To make democracy safe for the world.' This puts the program in the thought of the people on a level with the aims of the great war. It is not suggested here as a final statement of the goal of the missionary enterprise, but as one exceedingly, interesting and apropos for a present-day program.

In getting a people to accept willingly a great program, the educational factors are of great importance. The processes may not savour much of formal education, but the results in the permanent intelligent interest of the people will be quite as outstanding.

It may be necessary also to change the basis of church membership before a group of people banded together in what is known as a local church will accept normally a service program as their dominant purpose. The universal obligation to serve the common good would be a far more stimulating as well as exacting basis for church membership 
than formal or credal demands. Such an obligation interpreted according to the real needs of the world of to-day would express itself at once in the Church's missionary program.

It is my conviction that something comparable to the above must be undertaken by Christian leaders before the Church will look upon its missionary program as its dominant purpose and interest.

4. There is another and equally vital aspect of missionary education which presses its claim upon all those who are desirous of realizing a dominantly missionary Church. Missionaries and others who have had experience in appealing to a disinterested Church know all too well that their efforts are received as the seed in our Lord's parable of the sower. Some who call on the name of Christ are not interested in folks at all. Some are narrow in their vision or dwarfed in their sympathies. Others are selfish or let their lives run on a single track or are satisfied with perfunctory duties rather than the realization of justice.

There is a good deal of soil in the Church that is not fertile for service seeds. Why is this ? Must we take the hopeless attitude that people are foreordained to be unresponsive to the needs of others? It is just here that a thorough understanding of child life and of the processes of missionary education are absolutely necessary to any adequate program of religious training. We need to realize that there is an attitude, a disposition, a quality of life which in its sum total constitutes what may be known as the missionary life or spirit, and that this life can be educated in growing boys and girls. The personal qualities of friendliness, sympathy, helpfulness, co-operation, loyalty and justice are all subject to the laws of growth and cultivation. Indeed, the seeds of them all are already implanted in human nature in the God-given instincts which are at once the challenge and hope of educational endeavour. These qualities of life, properly trained and 
extended into right channels for expression, form just what is in this article conceived of as ' missionary.'

People who do not have these qualities can hardly be trusted to support the missionary enterprises faithfully and continually. On the other hand, those in whom they are well developed may be depended upon to seize eagerly the program referred to above and work at it devotedly. My own interest in them as the foundations of missionary character grew out of a study of the biographies of great missionaries. These men and women embodied in themselves the qualities of the missionary life, even as Jesus summed up in Himself the essentials of His gospel.

It will be noted that these traits of character are the social ones. They concern our relations with our fellows. Their significance for missionary education is just at this point. Because they are social, they are also in the realm of action. Suppose that the whole Christian body shouid begin to manifest these qualities sincerely and zealously in the normal relations of men in everyday life, would there not result a far greater and more compelling missionary propaganda than that of a legion of specially constituted emissaries ?

In the awakening and development of these qualitics of life, functioning again takes the central place. Herein, also, lies their relation to missionary service. Children become helpful by actually being helpful in the normal life of children. The same is true of all the other qualities. Formal education is here as valueless as it is later in attempting to arouse people whose early training has been so neglected and in whom, as a consequence, there are no predispositions to a life of service.

Feeling as we do to-day the necessity of a more faithful application of the social gospel, we should profit by our present extremity and begin the training of children and youth in those experiences which will make them useful members of the kingdom of God. To do this is, of course, a radical departure from the system of religious instruction 
with which we are familiar. This phase of religious education is what Professor George A. Coe has described and defended in his recent book as $\boldsymbol{A}$ Social Theory of Religious Education.

There are three terms which in the next generation we must bring together-Christian, missionary and church membership. If this can be done we can not only remove the odium that attaches itself in some quarters to the Church because it has failed, but we can make increasingly effective in the hearts of men the purpose of Jesus as expressed in His gospel. We will have a dominantly missionary Church, first, when we have an adequate, concrete and definite program of world conquest, and, second, when this program can be undertaken by a group in which the missionary qualities of life are fully awakened and developed.

RALPh E. Diffendobfer 